\title{
An integrated, peptide-based approach to site-specific protein immobilization for detection of biomolecular interactions
}

Citation for published version (APA):

Kruis, I. C., Löwik, D. W. P. M., Boelens, W. C., van Hest, J. C. M., \& Pruijn, G. J. M. (2016). An integrated, peptide-based approach to site-specific protein immobilization for detection of biomolecular interactions. Analyst, 141(18), 5321-5328. https://doi.org/10.1039/c6an00154h

\section{Document license: \\ TAVERNE}

DOI:

10.1039/c6an00154h

Document status and date:

Published: 21/09/2016

\section{Document Version:}

Publisher's PDF, also known as Version of Record (includes final page, issue and volume numbers)

\section{Please check the document version of this publication:}

- A submitted manuscript is the version of the article upon submission and before peer-review. There can be important differences between the submitted version and the official published version of record. People interested in the research are advised to contact the author for the final version of the publication, or visit the $\mathrm{DOI}$ to the publisher's website.

- The final author version and the galley proof are versions of the publication after peer review.

- The final published version features the final layout of the paper including the volume, issue and page numbers.

Link to publication

\section{General rights}

Copyright and moral rights for the publications made accessible in the public portal are retained by the authors and/or other copyright owners and it is a condition of accessing publications that users recognise and abide by the legal requirements associated with these rights.

- Users may download and print one copy of any publication from the public portal for the purpose of private study or research.

- You may not further distribute the material or use it for any profit-making activity or commercial gain

- You may freely distribute the URL identifying the publication in the public portal.

If the publication is distributed under the terms of Article 25fa of the Dutch Copyright Act, indicated by the "Taverne" license above, please follow below link for the End User Agreement:

www.tue.nl/taverne

Take down policy

If you believe that this document breaches copyright please contact us at:

openaccess@tue.nl

providing details and we will investigate your claim. 


\title{
Analyst
}

\section{PAPER}

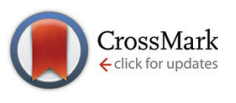

Cite this: Analyst, 2016, 141, 5321

\section{An integrated, peptide-based approach to site-specific protein immobilization for detection of biomolecular interactions $\uparrow$}

\author{
Ilmar C. Kruis, ${ }^{\text {a,b }}$ Dennis W. P. M. Löwik, ${ }^{b}$ Wilbert C. Boelens, ${ }^{a}$ Jan C. M. van Hest ${ }^{\text {b }}$ \\ and Ger J. M. Pruijn*a
}

\begin{abstract}
We have developed an integrated solution for the site-specific immobilization of proteins on a biosensor surface, which may be widely applicable for high throughput analytical purposes. The gold surface of a biosensor was coated with an anti-fouling layer of zwitterionic peptide molecules from which leucine zipper peptides protrude. Proteins of interest, the autoantigenic proteins La and U1A, were immobilized via a simple incubation procedure by using the complementary leucine zipper sequence as a genetically fused binding tag. This tag forms a strong coiled-coil interaction that is stable during multiple consecutive measurements and under common regeneration conditions. Visualization of the immobilized proteins of interest via antibody binding with multiplex surface plasmon resonance imaging demonstrated 2.5 times higher binding responses than when these proteins were randomly attached to the surface via the commonly applied activated ester-mediated coupling. The proteins could also be immobilized in a leucine zipper-dependent manner directly from complex mixtures like bacterial lysates, eliminating the need for laborious purification steps. This method allows the production of uniform functional protein arrays by control over immobilized protein orientation and geometry and is compatible with high-throughput procedures.
\end{abstract}

Received 22nd January 2016 Accepted 14th June 2016

DOI: 10.1039/c6an00154h

www.rsc.org/analyst binding of the ligand. ${ }^{5}$ This is suboptimal for sensitivity and creates variability between measurements.

To improve ligand immobilization, several strategies for site-specific protein immobilization have been developed. ${ }^{6,7}$ Some of these utilize bio-orthogonal reactions like copper-catalyzed and strain-promoted 'click' chemistry, ${ }^{8-11}$ oxime ligation $^{10,12}$ Staudinger ligation ${ }^{13}$ or enzymatic coupling reactions as those with sortase ${ }^{14}$ or phosphopantetheinyl transferase ${ }^{15}$ Others make use of non-covalent binding, such as facilitated by the use of affinity tags frequently used for protein purification ${ }^{16-20}$ or peptide tags that bind to the surface matrix, like pMMA. ${ }^{21}$ More alternatives are DNAdirected immobilization ${ }^{22,23}$ or enzymatic modification of the proteins, ${ }^{24-26}$ like localized biotinylation of a specific peptide tag using the BirA enzyme. ${ }^{27}$ However, these methods either rely on separate modification and coupling steps of the proteins involved, or have relatively weak binding properties.

Advances in SPR technology also put different demands on the immobilization chemistry. Surface Plasmon Resonance Imaging (iSPR) is a multiplex variant that is primarily used for the visualization of biomolecular interactions, generally on microarrays. ${ }^{1}$ With this approach, instead of a single biomolecule, multiple different biomolecules need to be immobilized simultaneously. As a consequence, coupling or modification steps that need individual optimization for distinct biomolecules, 
are undesirable. An immobilization method that is specific, strong and well controlled, yet versatile and simple enough to be used for multiple different biomolecules is not yet available.

Versatile, specific and strong binding can be found in socalled leucine zipper polypeptides. These are coiled-coil binding motifs, originating from the bZIP class of transcriptional regulator proteins. ${ }^{28}$ Their structure consists of a heptad repeat with a hydrophobic leucine on the binding interface, which gives them their name. Next to these leucines, the binding interface contains pairs of oppositely charged residues. By variation of these charged residues, affinity and specificity of leucine zippers can be engineered, and sets of heterospecific leucine zipper peptides have been developed. ${ }^{29,30}$ By optimizing binding strength, binding affinity up to a dissociation constant of $10^{-15} \mathrm{M}$ has been obtained, comparable to the well-established biotin-streptavidin interaction. ${ }^{31}$ Zhang et al. successfully applied leucine zipper polypeptides for immobilization of proteins, although in their approach an additional crosslinking reaction was still needed to functionalize the surface. ${ }^{32}$ Immobilization with coiled-coil domains was also shown by Ferrari et al., using the larger tetra-helical SNARE protein complex as connector. ${ }^{33}$

The aim of our study was to provide a generic, integrated solution for well-controlled immobilization of proteins on gold surfaces. Our approach (Fig. 1) utilizes a monolayer of short, zwitterionic peptides as anti-fouling layer on the gold surface. ${ }^{34}$ A fraction of the anti-fouling peptides is extended with a leucine zipper. This functionalizes the surface to allow binding of a complementary leucine zipper sequence, which is genetically fused to the proteins that are to be immobilized. This approach allows a strong, well-controlled immobilization of the fusion proteins using simple incubation with the functionalized surface. The autoantigenic human La and U1A proteins were used to demonstrate the applicability of this method. ${ }^{35}$

\section{Materials \& methods}

\section{Cloning}

An XhoI restriction site was introduced between the oligohistidine tag sequence and the attL1 site of a pDEST17 vector by site-directed mutagenesis. Partially overlapping oligonucleotides coding for the leucine zipper peptides ER (LEIEAAFLERENTALETRVAELRQRVQRLRNRVSQYRTRYGPLGGGGK) and RE (LEIRAAFLRQRNTALRTEVAELEQEVQRLENEVSQYETRYGPLGGGGK) flanked by XhoI sites (Biolegio, Nijmegen, The Netherlands) were converted to double-stranded molecules by PCR, digested by XhoI (New England Biolabs, Ipswitch, MA, USA) and the inserts isolated. The inserts were then ligated into the Xhol-linearized pDEST17 variant described above. E. coli ccdB survival $2 \mathrm{~T}^{\mathrm{R}}$ competent cells were transformed with these constructs and grown on media with $100 \mu \mathrm{g} \mathrm{mL} \mathrm{m}^{-1}$ carbenicillin and $34 \mu \mathrm{g} \mathrm{mL}{ }^{-1}$ chloramphenicol. This resulted in the pDNz-VinER and pDNz-VinRE plasmids (see ESI Fig. S1 and $\mathrm{S} 2 \dagger)$. La and U1A cDNAs were generated by PCR using cDNA constructs described previously ${ }^{36,37}$ and introduced into pENTR/TEV/D-TOPO vectors. Subsequently these were recombined in an LR-recombination reaction with pDEST17 and pDNz vectors using Gateway LR Clonase II mix and the resulting pDEST17-La, pDEST17-U1A, pDNz-VinER-La, pDNz-VinRE-La, pDNz-VinER-U1A and pDNz-VinRE-U1A vectors were used to transform E. coli TOP10 competent cells. Following plasmid isolation, the integrity of all constructs was confirmed by DNA sequencing. Cloning supplies were acquired from Invitrogen (Carlsbad, CA, USA) and chemicals from Sigma-Aldrich (St. Louis, MO, USA).

\section{Protein expression}

The constructs for the expression of unmodified and N-terminally leucine zipper-tagged $\mathrm{U} 1 \mathrm{~A}$ and La proteins were used to transform E. coli BL21 AI. An initial overnight culture in $5 \mathrm{~mL}$ LB was used to inoculate $1.5 \mathrm{~L} 2 \mathrm{TY}$ medium containing $100 \mu \mathrm{g} \mathrm{mL} \mathrm{m}^{-1}$ ampicillin. The bacteria were cultured at $37{ }^{\circ} \mathrm{C}$ and expression was induced (at OD 0.7) using $0.1 \%$ of $\mathrm{L}_{\mathrm{a}}$-arabinose and $0.5 \mathrm{mM}$ isopropyl $\beta$-D-1-thiogalactopyranoside (MP Biomedicals, Santa Ana, CA, USA), after which the bacteria were cultured overnight at $25{ }^{\circ} \mathrm{C}$. Cells were harvested and resuspended in $20 \mathrm{mM}$ Tris- $\mathrm{HCl}, \mathrm{pH} 8.0,500 \mathrm{mM} \mathrm{KCl}$ for NiNTA affinity purification or PBS for direct immobilization, lysed by sonication and cleared by centrifugation for $20 \mathrm{~min}$ at $29000 \mathrm{~g}$. For direct immobilization the crude lysates were

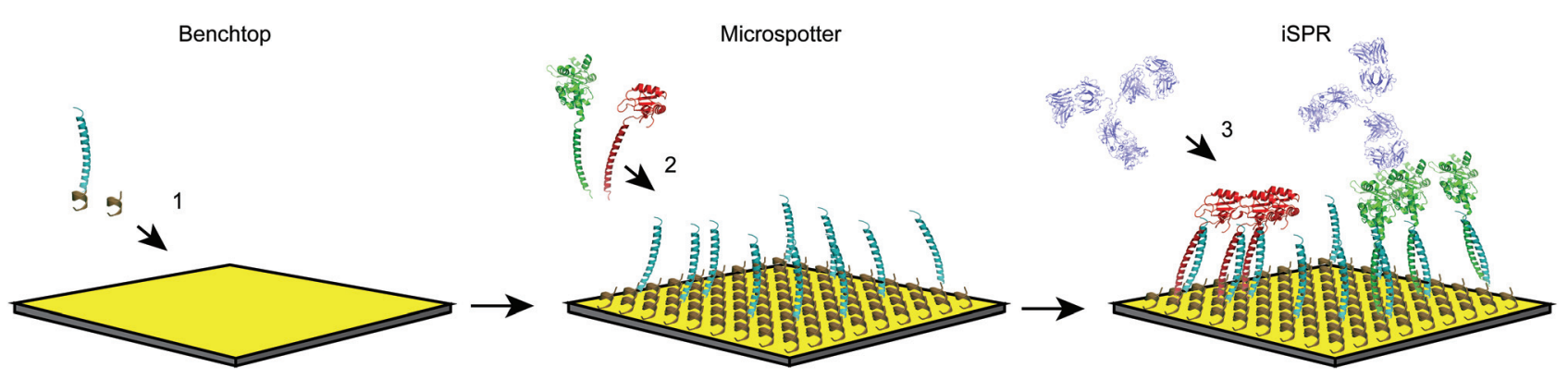

Fig. 1 Schematic representation of leucine-zipper mediated immobilization. Initially the gold surface of an iSPR biosensor is coated with antifouling peptides mixed with anti-fouling peptides extended with leucine zippers (1). One or more fusion proteins containing a single complementary leucine zipper peptide are then immobilized on the surface by incubation in a microspotter (2). Following immobilization antibody binding to the immobilized proteins is visualized using iSPR (3). 
cleared by gradual addition of poly(iminoethylene) to $0.02 \%$ and centrifugation for $20 \mathrm{~min}$ at $29000 \mathrm{~g}$. Lysates were then frozen by liquid nitrogen and stored in single-use aliquots at $-80{ }^{\circ} \mathrm{C}$. For purification the lysates were incubated with NiNTA sepharose (IBA Life Sciences, Goettingen, Germany) and the suspension was cast in a column. The column was washed with wash buffer (20 mM Tris- $\mathrm{HCl}, \mathrm{pH}$ 8.0, $500 \mathrm{mM} \mathrm{KCl}$, $20 \mathrm{mM}$ imidazole, $10 \%$ glycerol), wash buffer containing $1 \mathrm{M}$ $\mathrm{KCl}$ and wash buffer containing $50 \mathrm{mM}$ imidazole. Bound proteins were eluted (20 mM Tris- $\mathrm{HCl}, \mathrm{pH} 8.0,100 \mathrm{mM} \mathrm{KCl}$, $500 \mathrm{mM}$ imidazole, $10 \%$ glycerol) and analysed by SDS-PAGE. The buffer was then exchanged to PBS and samples were concentrated using $10 \mathrm{kDa}$ MWCO centrifugation filters (EMD Millipore, Billerica, MA, USA).

\section{Peptide synthesis}

Peptides were synthesized using standard Fmoc chemistry on Barlos resin. The resin was swollen in dimethylformamide (DMF). Fmoc groups were removed by washing with $20 \%$ piperidine in DMF while shaking for $20 \mathrm{~min}$. The desired amino acids were coupled using 3 eq. Fmoc-protected amino acid, 3.3 eq. diisopropylcarbodiimide and 3.6 eq. $N$-hydroxy benzotriazole for $40 \mathrm{~min}$ up to overnight as indicated by a negative Kaiser test. ${ }^{38}$ After final Fmoc removal, the resin was washed with DMF, dichloromethane and methanol and dried. Cleavage from the resin was performed using $90 \%$ trifluoroacetic acid, 5\% water, $2.5 \%$ triisopropylsilane and $2.5 \%$ thioanisole for 5 hours. After filtration from the resin the free peptide was precipitated in diethyl ether, dried in air, redissolved in water and lyophilized. LCMS was performed on a Thermo Finnigan LCQ-Fleet ESI-ion trap (Thermo Fischer, Breda, The Netherlands) equipped with Alltima C18 column, $2.1 \times 150 \mathrm{~mm}$, particle size $3 \mu \mathrm{m}$ (Alltech Applied Sciences, Breda, Netherlands) using an acetonitrile/water gradient with $0.1 \%$ formic acid.

\section{Chip preparation}

SensEye Au iSPR sensors (Ssens, Enschede, The Netherlands) were cleaned by incubation for $10 \mathrm{~min}$ with a $3: 1$ solution of sulphuric acid (analysis grade, 95-97\%) and 30\% hydrogen peroxide. Following incubation the chip was rinsed with Milli-Q water, ethanol and dried under nitrogen. The surface was subsequently coated with a peptide layer by overnight incubation with a mixture of $4.75 \mathrm{mM}$ anti-fouling peptide (MPA-LHDLHD) and $0.25 \mathrm{mM}$ leucine zipper-anti-fouling fusion peptide (RE: MPA-LHDLHDLEIRAAFLRQRNTALRTEVAELEQEVQRLENEVSQYETRYGPLGGGGK or ER: MPA-LHDLHDLEIEAAFLERENTALETRVAELRQRVQRLRNRVSQYRTRYGPLGGGGK) in Milli-Q water. After incubation the chip was rinsed thoroughly with Milli-Q.

\section{Protein immobilization}

Immobilization of purified, zipper-tagged La to the peptide surface was achieved by incubation with $150 \mathrm{ng} \mathrm{mL}{ }^{-1}$ of the protein in PBS containing $0.075 \%$ Tween-80 during $1 \mathrm{~h}$ in a Continuous Flow Microspotter (Wasatch Microfluidics, Salt Lake City, UT, USA), equipped with a printhead for up to 48 spots of approximately $0.1 \mathrm{~mm}^{2}$ each. This incubation was followed by a 2 min washing step.

For immobilization of zipper-tagged La using crude bacterial lysates, Tween-20 was added to a final concentration of $0.1 \%$ vol. before similar incubation in the microspotter.

Covalent immobilization to the peptide-surface was performed by activation for $30 \mathrm{~min}$ with $50 \mathrm{mM}$ 1-ethyl-3-(3dimethyl-aminopropyl)carbodiimide and $250 \mathrm{mM}$ sulfo-( $N$ hydroxy-succinimide) (NHS) in $10 \mathrm{mM}$ 2-(N-morpholino)ethanesulfonic acid (MES) followed by $1 \mathrm{~h}$ incubation with $150 \mathrm{ng}$ $\mathrm{mL}^{-1}$ non-tagged La protein in sodium acetate $\mathrm{pH} 4.5$.

\section{iSPR analysis}

Performance of the peptide anti-fouling layer was tested by preparing a chip as described under chip preparation. For comparison a SensEye Easy2Spot-P (Ssens, Enschede, The Netherlands) chip with planar NHS ester functionality was used and blocked by incubation for $10 \mathrm{~min}$ with a $1 \mathrm{M}$ 2-aminoethanol solution in $10 \mathrm{mM}$ MES pH 5.5. For analysis of the non-specific binding to these surfaces, zipper-tagged La and serum proteins were diluted in system buffer (PBS containing $0.075 \%$ Tween-80) to final concentrations of $100 \mu \mathrm{g} \mathrm{mL} \mathrm{m}^{-1}$. Binding of these proteins was visualized in an IBIS MX96 iSPR over a period of $30 \mathrm{~min}$ and analysed using SPRintX software (IBIS Technologies, Enschede, The Netherlands) by equalization of baselines and determination of the response at the end of the binding phase.

Immobilization of the leucine zipper-tagged protein was visualized by preparation of the anti-fouling layer as described under chip preparation, followed by $30 \mathrm{~min}$ incubation in the IBIS MX96 iSPR with 60, 12 and $6 \mu \mathrm{g} \mathrm{mL}{ }^{-1}$ zipper-tagged La in system buffer, 8 min buffer wash and 1 min regeneration with $6 \mathrm{M}$ guadinine-HCl. Analysis was performed with SPRintX software and baselines equalized.

Visualization of the immobilized leucine zipper-tagged proteins using antibodies was performed by preparation of a leucine-zipper functionalized chip as described under chip preparation. After immobilization of either the purified proteins or the proteins from crude lysate, the first measurement and regeneration cycle was performed with system buffer (in case of purified proteins) or with $1 \mathrm{M} \mathrm{NaCl}$ (in case of the crude lysate). Binding of monoclonal antibody (a 1:20 dilution of culture supernatant containing $5 \%$ serum in system buffer, resulting in approximately $1 \mu \mathrm{g} \mathrm{mL}^{-1}$ antibody according to SDS-PAGE analysis) was visualised in the IBIS MX96 iSPR for $40 \mathrm{~min}$, followed by $8 \mathrm{~min}$ dissociation and $1 \mathrm{~min}$ regeneration with $10 \mathrm{mM}$ glycine- $\mathrm{HCl}, \mathrm{pH}$ 2.0, unless stated otherwise. Analysis was performed with SPRintX software; the chip surface was calibrated according to the manufacturer's instructions, baselines were equalized and the response was determined at the end of the binding phase, when binding was close to equilibrium.

\section{Statistical analyses}

Significance of the differences in protein-binding to the antifouling layers and of the antibody-binding to the La protein 
immobilized using a leucine zipper tag or using covalent coupling was assessed using an unpaired, one-way ANOVA with Tukey-test. Significance between the responses from antibodybinding to leucine zipper-tagged and untagged protein pairs immobilized from crude lysate was assessed using a $t$-test. All statistical analyses were performed using Graphpad Prism 5 (Graphpad Software, La Jolla, CA, USA).

\section{Results and discussion}

\section{Peptide-based self-assembled monolayer for antifouling}

The gold surface of an iSPR chip is typically covered with either a dextran hydrogel or a monolayer of carboxyl-terminated alkane thiols to avoid non-specific interactions with the gold and to provide functional groups for immobilization. Good results have also been reported with zwitterionic polymers. ${ }^{39,40}$ More recently, Masson and co-workers developed monolayers of various zwitterionic peptides with an $\mathrm{N}$-terminal 3-mercaptopropionic acid (MPA) for surface attachment, ${ }^{34,41}$ which provide a similar function. For our purpose, we selected the anti-fouling peptide consisting of MPA - Leu His - Asp - Leu - His - Asp, which showed good anti-fouling properties with serum as analyte solution. ${ }^{19}$ This peptide was synthesized using Fmoc solid-phase peptide synthesis and its integrity and purity were confirmed with LC-MS (ESI Fig. S3†).

In order to assess anti-fouling performance, non-specific binding to the gold surface of an iSPR sensor coated with the anti-fouling peptide was investigated by exposing the coated surface to high concentrations of either a purified recombinant protein or a crude biological sample (serum). The coated surface was incubated with a high concentration, $100 \mu \mathrm{g} \mathrm{mL} \mathrm{m}^{-1}$, of leucine zipper-tagged La protein, a putative RNA chaperone which is a target for autoantibodies in patients with systemic lupus erythematosus and Sjögren's syndrome, ${ }^{35}$ or with a similar concentration of bovine serum proteins in PBS containing $0.075 \%$ Tween-80. Serum proteins were chosen because they were also present during subsequent antibody binding experiments (see below). The non-specific binding to the peptide layer was compared with binding to a comparable, commercially available alternative with a planar, NHS esterfunctionalised surface chemistry blocked with 2-aminoethanol.

After incubation with the purified protein solution for 30 minutes, non-specific binding to the iSPR chip was approximately equal for both tested layers, while after incubation with the serum proteins a considerably lower non-specific binding was observed with the peptide layer (Fig. 2). These results showed that the peptide-based layer has indeed good antifouling properties which are particularly useful for measuring antibody interactions.

\section{Leucine zipper based immobilisation for iSPR}

To provide stable immobilization, a leucine zipper pair with high affinity, yet low homodimerization properties is desired. Such a pair was previously described by Moll and coworkers (peptide RE: LEIRAAFLRQRNTALRTEVAELEQEVQRLENEVS-

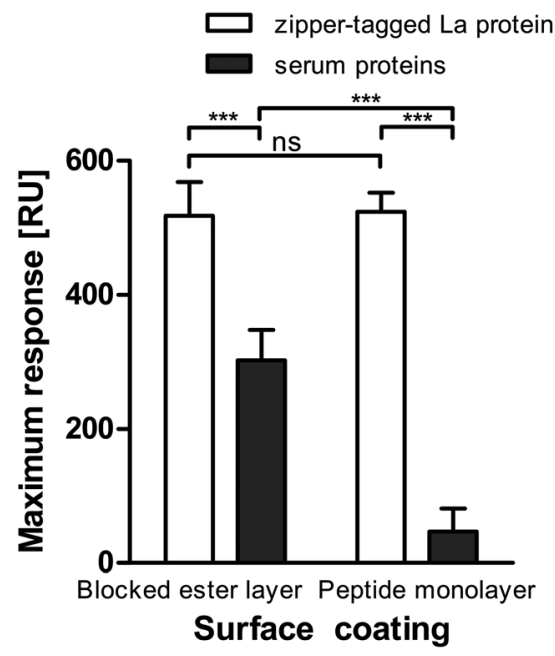

Fig. 2 Anti-fouling properties of zwitterionic peptide monolayer. The response due to non-specific binding to the peptide monolayer is compared with a commercially available chip with planar, NHS ester-functionalised surface chemistry that was blocked using 2-aminoethanol. Analytes were $100 \mu \mathrm{g} \mathrm{ml}^{-1}$ zipper-tagged La protein and approximately $100 \mu \mathrm{g} \mathrm{ml}^{-1}$ serum proteins in PBS containing $0.075 \%$ Tween-80. Bars represent the mean with standard deviation of triplicate analyses. Significance of differences ( $* * *: p \leq 0.001$; ns: non-significant) was assessed using a one-way ANOVA with Tukey test. RU: response units.

QYETRYGPLGGGGK and peptide ER: LEIEAAFLERENTALETRVAELRQRVQRLRNRVSQYRTRYGPLGGGGK). ${ }^{31}$ Both leucine zipper peptides were synthesized with the anti-fouling sequence and 3-mercaptopropionic acid at the N-terminus (ESI Fig. S4 and S5 $\dagger$ ). This allowed the attachment of either peptide to the gold surface of an iSPR sensor, with the leucine zipper peptide protruding from the monolayer of anti-fouling peptides (Fig. 1). A 20-fold molar excess of anti-fouling peptide compared to leucine zipper peptide was used to create an antifouling layer which will yield a high density of immobilized leucine zipper molecules.

The cloning of sequences coding for a target protein fused to a leucine zipper was performed with the Gateway system, ${ }^{42}$ which allows efficient transfer of DNA-fragments between plasmids by recombination cloning. To facilitate high-throughput cloning of zipper-fusion constructs, the pDEST17 vector of the Gateway system was modified by the incorporation of either the ER or the RE sequence. This resulted in the pDNz-VinER and pDNz-VinRE plasmids (see ESI Fig. S1, S2 and Table S1†), which after incubation with the recombination enzyme mix and the pENTR vector containing the cDNA of the target La protein, led to the desired leucine zipper fusion expression construct. The constructs for the ER- and RE-tagged La protein obtained this way, were expressed in E. coli using standard techniques (ESI Fig. S6†). After purification, the recovered yield of soluble fusion protein was somewhat lower compared to the unmodified La protein (data not shown), which might be due to an increased tendency of the tagged protein to aggregate.

To immobilize the fusion protein, the leucine zipper-functionalised surface was incubated with the purified fusion 
a)

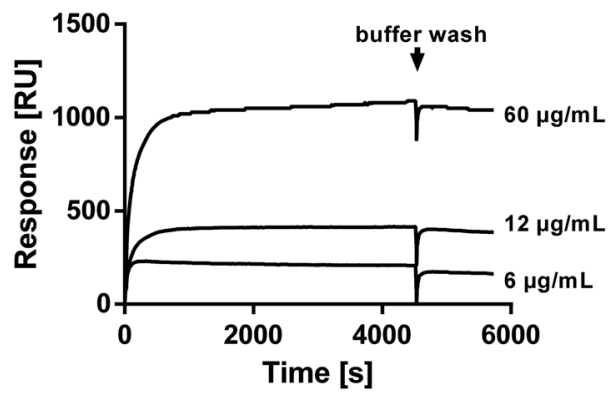

b)

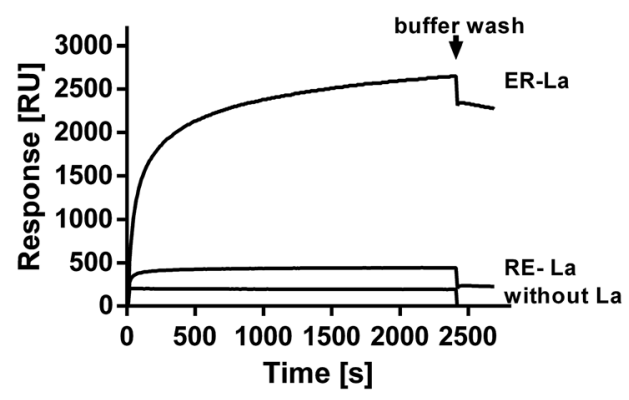

Fig. 3 Leucine zipper-based immobilization of the La protein on an iSPR surface. (a) Sensorgram visualizing binding of 60,12 and $6 \mu \mathrm{g} \mathrm{ml}^{-1}$ of zipper-tagged La protein to the complementary zipper peptide on the iSPR surface. Binding was performed in PBS containing $0.075 \%$ Tween- 80 for $4500 \mathrm{~s}$, after which dissociation conditions (buffer wash) were applied for $1500 \mathrm{~s}$. (b) Sensorgram visualizing binding of $1 \mu \mathrm{g} \mathrm{ml} \mathrm{l}^{-1}$ anti-La monoclonal antibody sw5 to the La protein, immobilized using standard conditions $\left(150 \mathrm{ng} \mathrm{m}^{-1}\right)$ in a microspotter and tagged with a leucine zipper complementary (ER) or non-complementary (RE) to the sensor surface. Binding was performed in PBS containing $0.075 \%$ Tween-80 for $2400 \mathrm{~s}$, after which dissociation conditions (buffer wash) were applied for $480 \mathrm{~s}$. RU: response units.

protein containing a complementary zipper sequence and the immobilization was monitored by iSPR (ESI Fig. S7†). The resulting sensorgram (Fig. 3a) shows swift association of the fusion protein and very slow dissociation during a buffer wash, reflecting the very stable non-covalent interaction. Consequently, dissociation was negligible during the timeframe of SPR measurements.

Using a continuous flow microspotter with an array of microfluidics flow cells, individual 'spots' on a sensor chip were incubated with either fusion proteins with complementary and non-complementary zipper sequences to assess the specificity of immobilization. A traditional activated ester coupling was performed in parallel to compare leucine zipper-based with covalent immobilization. The entire sensor chip was incubated with antibodies against the La protein, to visualize the immobilized proteins (Fig. 3b, 4 and ESI Fig. S8†). The complementary zipper-tagged La protein indeed was efficiently immobilized on the surface, whereas the antibody-binding signals for the non-complementary zipper-tagged protein were hardly detectable, indicating that the latter was not, or only very inefficiently, immobilized. This substantiates the specificity of zipper-based immobilization. Antibody-binding to zipper-immobilized protein was higher than when the protein was covalently bound to the surface. These observations reflect those of previous reports ${ }^{6,43}$ that site-specific protein immobilization improves the binding response. With site-specific immobilization the protein structure is better preserved, resulting in less non-binding protein molecules on the surface. Also the accessibility of binding sites for the antibodies might have been improved due to a more favourable orientation of the immobilized protein. In addition, it should be noted that we can not exclude the possibility that covalent immobilization led to a lower amount of protein immobilized on the surface compared to the zipper-mediated immobilization.

For multiple binding experiments on a single chip it is important that the immobilized proteins are resistant to regeneration procedures. In typical SPR measurements the ligand is immobilized on the surface once and after a binding experi- a)

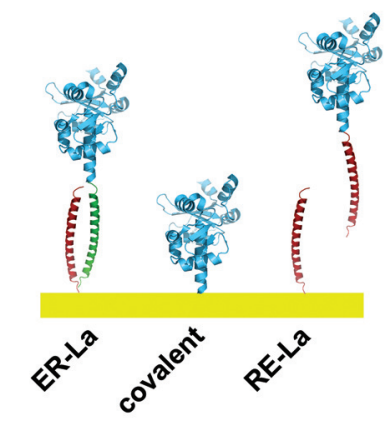

b)

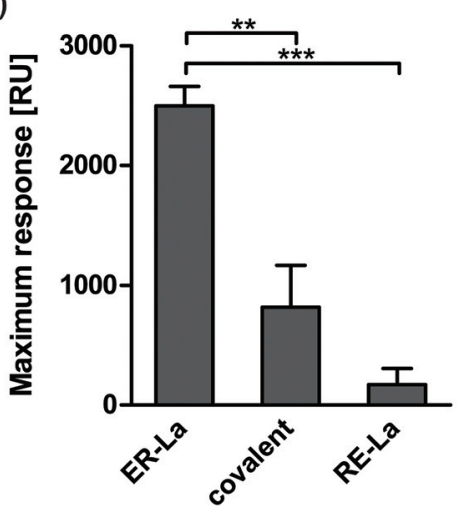

Fig. 4 Specificity of leucine zipper-based immobilization detected by antibody binding. (a) Zipper-tagged La protein was immobilized on a RE leucine zipper-functionalized sensor surface using, from left to right, a complementary (ER) leucine zipper-tag, activated-ester mediated covalent coupling and a non-complementary (RE) leucine zipper tag. (b) Maximum iSPR responses for anti-La antibody binding to the immobilized La protein. Bars represent the mean of triplicate analyses with standard deviation for $1 \mathrm{\mu g} \mathrm{ml}^{-1}$ anti-La monoclonal antibody sw5 binding in PBS containing $0.075 \%$ Tween- 80 . Significance of differences ( $* *$ : $p \leq$ $0.01,{ }^{* * *}: p \leq 0.001$ ) was assessed using a one-way ANOVA with Tukey test. RU: response units.

ment, the bound analyte is removed from the surface by a regeneration step, allowing the next binding experiment. For bound antibodies this regeneration step is commonly per- 


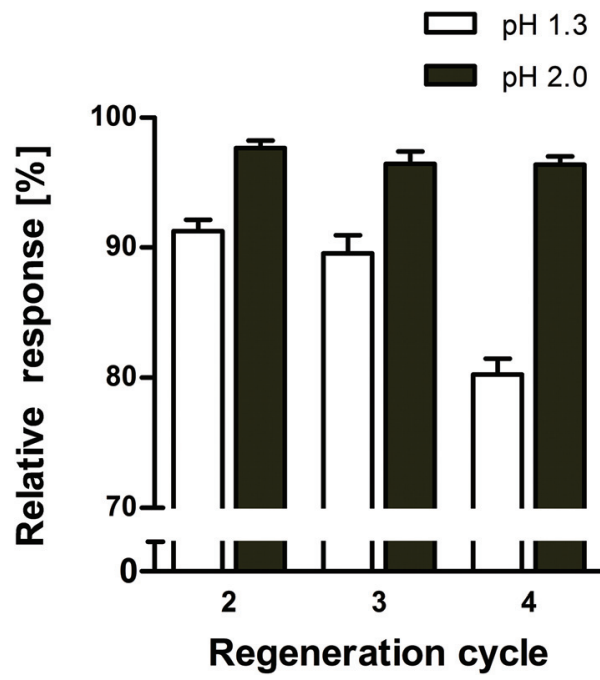

Fig. 5 Relative response of antibody-binding after consecutive regeneration cycles. Each cycle consisted of incubation with antibodies, followed by regeneration with $10 \mathrm{~mm}$ glycine- $\mathrm{HCl}$ of $\mathrm{pH} 1.3$ or $\mathrm{pH} 2.0$. The mean is shown with standard deviation of triplicate analyses with $1 \mu \mathrm{g}$ $\mathrm{ml}^{-1}$ anti-La monoclonal antibody sw5 in PBS containing $0.075 \%$ Tween-80.

formed by a short incubation with a low $\mathrm{pH}$ solution. ${ }^{44}$ For optimal regeneration the maximum response should remain constant over multiple measurement cycles. With a relatively harsh treatment at $\mathrm{pH} 1.3$ the maximum response for the binding of anti-La antibody to the zipper-La protein showed a clear reduction, with a total decrease after 4 cycles of approximately $20 \%$, most likely due to detachment or denaturation of the immobilized protein (Fig. 5). However, under somewhat milder regeneration conditions ( $\mathrm{pH}$ 2.0) the response remained stable and the total decrease after 4 cycles was less than $5 \%$. These data indicate that it is possible to selectively remove the bound antibody from the surface, while the immobilized proteins remain intact and available for binding during several consecutive measurements and surface regenerations.

Although the immobilization of proteins is simplified by using the leucine zipper-mediated approach, the laborious fusion protein expression and purification steps still remain. To reduce the amount of work involved, the specificity of leucine zipper-binding can also be employed to immobilize fusion proteins directly from crude bacterial lysates. Besides the previously used La protein, a second autoantigenic protein was used, U1A, a protein component of the U1 small nuclear ribonucleoprotein particle. ${ }^{35}$ The lysates of both fusion proteins were first cleared from insoluble material and bacterial DNA by two centrifugation steps and precipitation using poly (iminoethylene). The cleared lysates were then applied to the zipper-functionalized surface and after incubation the surface was rinsed thoroughly to remove non-bound material. Immobilized proteins were visualized by measuring antibody binding using iSPR. The results in Fig. 6 show that the leucine zipper-tagged U1A and La proteins were indeed immobilized

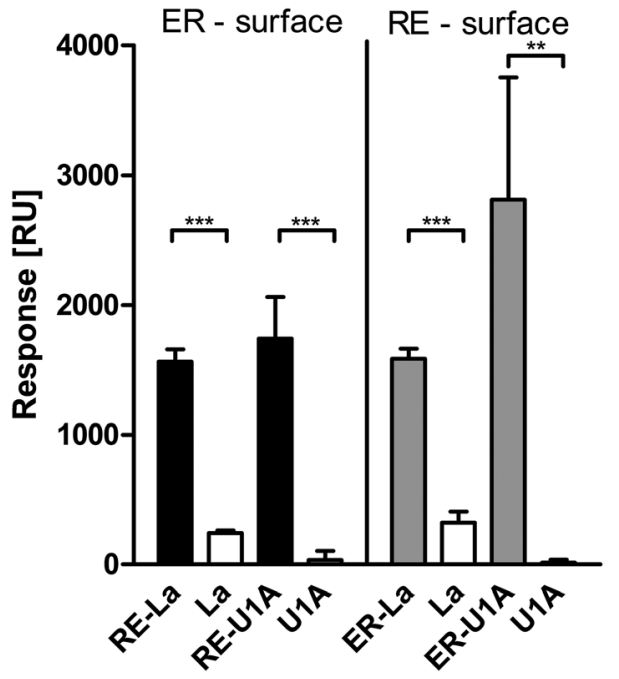

Fig. 6 Immobilization of leucine zipper-tagged proteins from crude bacterial lysates. Antibody-binding response to spots incubated with crude cell lysates containing fusion proteins with complementary (REtagged protein on ER surface and vice versa) zipper sequences and untagged proteins, on a surface functionalized with the ER peptide (black/white) and the RE peptide (grey/white). The bars represent the mean of triplicate analyses with standard deviations for $1 \mu \mathrm{g} \mathrm{ml}^{-1}$ anti-La monoclonal antibody sw5 and anti-U1A monoclonal antibody 9a9 in PBS containing $0.075 \%$ Tween-80. Significance of differences $(* *: p \leq$ $0.01, * \star *: p \leq 0.001$ ) between tagged and untagged protein pairs was assessed using a t-test.

by binding to the complementary zipper peptides, while untagged proteins were largely washed away, demonstrating that crude cell lysates can be employed for leucine zipperbased ligand immobilization.

While leucine zipper-based immobilization is potentially widely applicable, the leucine zipper sequence, although shorter than the previously mentioned SNARE complex, ${ }^{33}$ is relatively long compared to the moieties used for the execution of covalent coupling strategies. This might be a disadvantage in experiments where the length of this element is of importance. Additionally, the incorporation of a sequence of this length increases the risk that it interferes with proper protein folding or that steric effects influence the accessibility of important regions of the protein. Like other techniques which rely on fused peptide tags, such as a sortase- or ybbR-tags, ${ }^{14,15}$ this potentially limits the available orientations in which a protein can be immobilized and may restrict applications particularly to proteins with free $\mathrm{N}$ - or C-termini. In contrast to covalent immobilization strategies, the non-covalent nature of the leucine zipper-tags provides an opportunity to regenerate a biosensor surface for the analysis of unrelated biomolecular interactions by denaturing the coiled-coil structure.

\section{Conclusions}

We have demonstrated that leucine zippers as fusion tags can successfully be used as an integrated system for well- 
controlled, site-specific immobilization of proteins on surfaces, e.g. for SPR analysis. A peptide-based anti-fouling layer on the bare gold surface of an iSPR chip allows functionalization of the surface with leucine zippers, without additional coupling or capturing steps and with comparable anti-fouling performance to commercially available alternatives. Two model proteins were genetically fused to a leucine zipper sequence using a high-throughput cloning procedure, and effectively immobilized on such a surface by leucine zipper heterodimerization. Availability of the immobilized proteins was subsequently assessed by incubation with antibodies, where the antibody binding response for protein immobilized using leucine zippers was higher than that observed for a classical, random, activated ester-based coupling strategy. Although non-covalent and reversible, leucine zipper-based immobilization was stable in the time-frame of SPR measurements and not affected by regeneration conditions commonly used in antibody-based assays. This way of immobilization does not necessarily require purification of tagged proteins from crude cell lysates, further reducing the time and effort involved in immobilization. The minimal number of intermediate steps in the immobilization procedure minimizes the risk for undesired heterogeneity on the surface. The compatibility with highthroughput procedures and the simple incubation steps make leucine-zipper mediated immobilization ideally suited for applications which involve a multitude of proteins to be analysed, like multiplex iSPR.

\section{References}

1 S. Scarano, M. Mascini, A. P. F. Turner and M. Minunni, Biosens. Bioelectron., 2010, 25, 957-966.

2 R. L. Rich and D. G. Myszka, J. Mol. Recognit., 2008, 21, 355-400.

3 B. Johnsson, S. Löfås and G. Lindquist, Anal. Biochem., 1991, 198, 268-277.

4 Biacore AB, Biacore Sensor Surface Handbook, Biacore AB, Version AA, BR-1005-71, Uppsala, Sweden, 2003.

5 A. K. Trilling, M. M. Harmsen, V. J. B. Ruigrok, H. Zuilhof and J. Beekwilder, Biosens. Bioelectron., 2012, 40, 219-226.

6 A. Makaraviciute and A. Ramanaviciene, Biosens. Bioelectron., 2013, 50, 460-471.

7 E. Steen Redeker, D. T. Ta, D. Cortens, B. Billen, W. Guedens and P. Adriaensens, Bioconjugate Chem., 2013, 24, 1761-1777.

8 A. E. M. Wammes, M. J. E. Fischer, N. J. de Mol, M. B. van Eldijk, F. P. J. T. Rutjes, J. C. M. van Hest and F. L. van Delft, Lab Chip, 2013, 13, 1863-1867.

9 C. Tassa, M. Liong, S. Hilderbrand, J. E. Sandler, T. Reiner, E. J. Keliher, R. Weissleder and S. Y. Shaw, Lab Chip, 2012, 12, 3103-3110.

10 Z. P. Tolstyka, W. Richardson, E. Bat, C. J. Stevens, D. P. Parra, J. K. Dozier, M. D. Distefano, B. Dunn and H. D. Maynard, ChemBioChem, 2013, 14, 2464-2471.
11 M.-H. Seo, J. Han, Z. Jin, D.-W. Lee, H.-S. Park and H.-S. Kim, Anal. Chem., 2011, 83, 2841-2845.

12 E. H. M. Lempens, B. A. Helms, M. Merkx and E. W. Meijer, ChemBioChem, 2009, 10, 658-662.

13 J. Kalia, N. L. Abbott and R. T. Raines, Bioconjugate Chem., 2007, 18, 1064-1069.

14 M. Raeeszadeh-Sarmazdeh, R. Parthasarathy and E. T. Boder, Colloids Surf., B, 2015, 128, 457-463.

15 S. W. Lu, J. Thirlway and J. Micklefield, J. Am. Chem. Soc., 2008, 130, 12456-12464.

16 L. Nieba, S. E. Nieba-Axmann, A. Persson, M. Hämäläinen, F. Edebratt, A. Hansson, J. Lidholm, K. Magnusson, А̊. F. Karlsson and A. Plückthun, Anal. Biochem., 1997, 252, 217-228.

17 G. B. Sigal, C. Bamdad, A. Barberis, J. Strominger and G. M. Whitesides, Anal. Chem., 1996, 68, 490-497.

18 D. L. Johnson and L. L. Martin, J. Am. Chem. Soc., 2005, 127, 2018-2019.

19 O. R. Bolduc, P. Lambert-Lanteigne, D. Y. Colin, S. S. Zhao, C. Proulx, D. Boeglin, W. D. Lubell, J. N. Pelletier, J. Féthière, H. Ong and J.-F. Masson, Analyst, 2011, 136, 3142-3148.

20 J. F. Young, H. D. Nguyen, L. Yang, J. Huskens, P. Jonkheijm and L. Brunsveld, ChemBioChem, 2010, 11, 180-183.

21 Y. Kumada, Y. Ishikawa, Y. Fujiwara, R. Takeda, R. Miyamoto, D. Niwa, S. Momose, B. Kang and M. Kishimoto, J. Immunol. Methods, 2014, 411, 1-10.

22 C. Boozer, J. Ladd, S. Chen, Q. Yu, J. Homola and S. Jiang, Anal. Chem., 2004, 76, 6967-6972.

23 E. D. Wold, R. McBride, J. Y. Axup, S. A. Kazane and V. V. Smider, Bioconjugate Chem., 2015, 26, 807-811.

24 S. Duffy, K. Tsao and D. S. Waugh, Anal. Biochem., 1998, 262, 122-128.

25 P. Saviranta, T. Haavisto, P. Rappu, M. Karp and T. Lövgren, Bioconjugate Chem., 1998, 9, 725-735.

26 F. Clow, J. D. Fraser and T. Proft, Biotechnol. Lett., 2008, 30, 1603-1607.

27 B. K. Kay, S. Thai and V. V. Volgina, Methods Mol. Biol., 2009, 498, 185-198.

28 C. Vinson, P. Sigler and S. McKnight, Science, 1989, 246, 911-916.

29 H. Gradišar and R. Jerala, J. Pept. Sci., 2011, 17, 100-106.

30 A. W. Reinke, R. A. Grant and A. E. Keating, J. Am. Chem. Soc., 2010, 132, 6025-6031.

31 J. R. Moll, S. B. Ruvinov, I. Pastan and C. Vinson, Protein Sci., 2001, 10, 649-655.

32 K. Zhang, M. R. Diehl and D. A. Tirrell, J. Am. Chem. Soc., 2005, 127, 10136-10137.

33 E. Ferrari, F. Darios, F. Zhang, D. Niranjan, J. Bailes, M. Soloviev and B. Davletov, J. Nanobiotechnol., 2010, 8, 9.

34 O. R. Bolduc, C. M. Clouthier, J. N. Pelletier and J.-F. Masson, Anal. Chem., 2009, 81, 6779-6788.

35 W. J. van Venrooij and G. J. Pruijn, Curr. Opin. Immunol., 1995, 7, 819-824.

36 P. T. Sillekens, W. J. Habets, R. P. Beijer and W. J. van Venrooij, EMBO J., 1987, 6, 3841-3848. 
37 G. J. Pruijn, R. L. Slobbe and W. J. van Venrooij, Nucleic Acids Res., 1991, 19, 5173-5180.

38 E. Kaiser, R. L. Colescott, C. D. Bossinger and P. I. Cook, Anal. Biochem., 1970, 34, 595-598.

39 J. Ladd, Z. Zhang, S. Chen, J. C. Hower and S. Jiang, Biomacromolecules, 2008, 9, 1357-1361.

40 Z. Zhang, T. Chao, S. Chen and S. Jiang, Langmuir, 2006, 22, 10072-10077.

41 O. R. Bolduc, J. N. Pelletier and J.-F. Masson, Anal. Chem., 2010, 82, 3699-3706.
42 F. Katzen, Exp. Opin. Drug Discovery, 2007, 2, 571589.

43 A. K. Trilling, T. Hesselink, A. Van Houwelingen, J. H. G. Cordewener, M. A. Jongsma, S. Schoffelen, J. C. M. Van Hest, H. Zuilhof and J. Beekwilder, Biosens. Bioelectron., 2014, 60, 130-136.

44 J. J. van Beers, A. Willemze, J. J. Jansen, G. H. Engbers, M. Salden, J. Raats, J. W. Drijfhout, A. H. van der Helm-van Mil, R. E. Toes and G. J. Pruijn, Arthritis Res. Ther., 2013, 15, R140. 